\title{
Great East Japan Earthquake damage and local government relief
}

\author{
C. Doi \& M. Taniguchi \\ Graduate School of Systems and Information Engineering, \\ University of Tsukuba, Japan
}

\begin{abstract}
Japan sustained catastrophic damage from The Great East Japan Earthquake and its consequent tsunami on March 11, 2011. Those events caused economic losses estimated at more than 210 billion US dollars. Moreover, the disasters demonstrated the threat of natural disasters to other nations. Local governments affected by the earthquake depended on assistance offered by other local governments because they faced dire but unpredicted circumstances. Many researchers have examined international assistance, but no comprehensive perspective of assistance from other domestic areas has been reported. Improving the organization of assistance from all parts of Japan is an urgent necessity for preparation for large-scale disasters. This study analyzed Japanese local government websites, particularly examining all aspects of their support motivation and their actual support conditions. Data used for the study were downloaded from 1554 Japanese local governments' websites, except for those which applied the Disaster Relief Act. Data were collected from websites under strict rules to produce objective analyses. Descriptions on websites were related to their assistance efforts after The Great East Japan Earthquake such as charity, supply of goods, physical support, provision of municipal houses, and recruiting of field activities. The database was created from information extracted from numerous websites, including its contexts. The extracted information included descriptions of the presence or absence of assistance, victims and destinations of assistance, etc. Results show that some local governments were helping stricken regions via neighboring areas based on local extended government unions. Relations among local governments are important to facilitate their voluntary assistance to other regions and their government associations. Moreover, daily interregional exchange can assist mutual assistance in extreme situations.
\end{abstract}


Keywords: assistance, domestic local governments, motivation, Great East Japan Earthquake.

\section{Introduction}

On March 11, 2011, a strong earthquake with a magnitude of 9.0 convulsed for several minutes throughout eastern Japan. It registered the greatest magnitude since observations had begun to be taken in Japan. The large-scale natural disaster, designated thereafter as "The Great East Japan Earthquake", inflicted catastrophic damage on Japan and laid bare the threat of unusually destructive natural disasters to other countries.

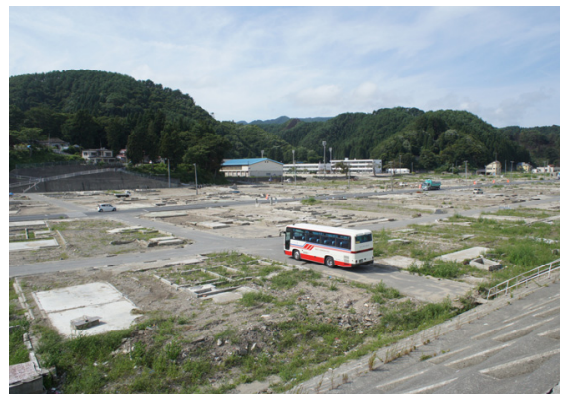

Figure 1: Tsunami damage.

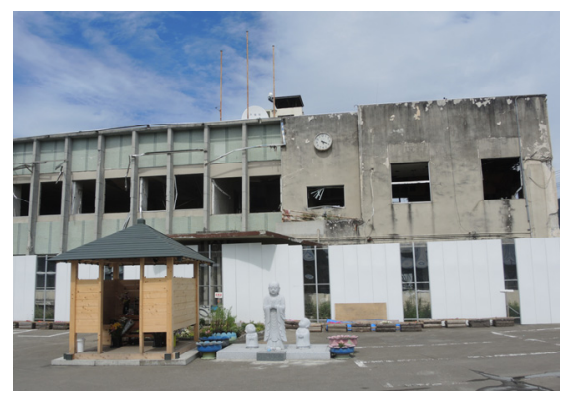

Figure 2: Disaster damage.

Table 1 presents an outline of the damage sustained from The Great East Japan Earthquake [1]. It caused about 16,000 deaths, but also taking 2,600 missing persons. Demolished buildings were about 130,000; half-destroyed structures were 270,000. The earthquake and tsunami caused economic losses estimated at more than 210 billion US dollars based on the amount of damage to buildings, lifeline facilities, and social infrastructure facilities [2]. Statistical data compiled by the Centre for Research on the Epidemiology of Disasters (CRED) show that natural disasters worldwide have caused heavy damage when tallied financially [3, 4]. The list includes The Great Hanshin-Awaji Earthquake of 1995 in Japan (100 billion US dollars), Hurricane Katrina of 2005 in the United States (125 billion US dollars), The Great Sichuan Earthquake of 2008 in China (85 billion US dollars). The Great East Japan Earthquake damage substantially exceeded the damage inflicted by those disasters. It is regarded as the earthquake disaster causing the greatest amount of damage in world history.

Local governments affected by the earthquake depended on assistance offered by other local governments because they faced unpredicted dire circumstances [5]. Much assistance was provided from foreign countries, such as assistance by US military forces. The Japanese Cabinet Office reported on October 17, 2011 that 163 countries or regions and 43 agencies announced their intentions to assist [6]. Many studies and information are associated specifically with international assistance efforts. 
Table 1: Outline of damage from The Great East Japan Earthquake [1].

\begin{tabular}{|c|c|}
\hline \multirow{3}{*}{$\begin{array}{l}\text { Dead and Injured } \\
\text { (as at September 11, 2014) }\end{array}$} & Dead: 15,889 people \\
\hline & Missing: 2,601 people \\
\hline & Injured: 6,152 people \\
\hline \multirow{3}{*}{$\begin{array}{l}\text { Building damage } \\
\text { (as of September 11, 2014) }\end{array}$} & Demolished buildings: 127,367 buildings \\
\hline & $\begin{aligned} & \text { Half destroyed building: } 273,335 \text { buildings } \\
& \text { (as at March 14, 2011) }\end{aligned}$ \\
\hline & $\begin{array}{l}\text { Partial damage: } 744,539 \text { buildings } \\
\qquad \text { (as at September } 11,2014)\end{array}$ \\
\hline \multirow{2}{*}{ Refugee } & Maximum: 470,000 people \\
\hline & Present: 245,622 people \\
\hline Estimated economic loss & 210 billon US dollars \\
\hline Disaster waste, etc. & $3,120,000 \mathrm{t}$ (as at end of July, 2012) \\
\hline
\end{tabular}

Reference: Japanese Cabinet Office

Much assistance was also provided from other domestic areas $[5,6]$. Nevertheless, no report of the relevant literature has provided a comprehensive perspective of that assistance. The Japanese Reconstruction Agency and Ministry of Internal Affairs and Communications reported the dispatch of municipal employees for assistance activities. However, no report has presented reference information related to preparation for large-scale disasters such as their tasks or activities in affected areas, and what jobs they normally hold [7, 8].

Improving the organization of assistance from all parts of Japan is an urgent necessity for preparation for possible future large-scale disasters. Therefore, this study analyzed all aspects of Japanese local government websites, particularly addressing their support motivation, and ascertained their actual support conditions. Finally, we attempt to present useful information to build the organization of assistance from domestic local governments.

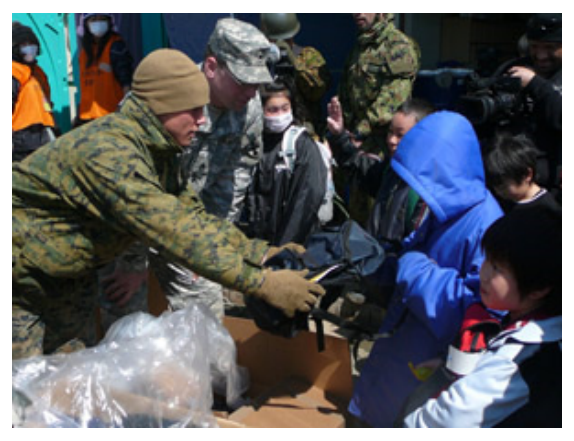

Figure 3: Support by US forces (Reference: Ministry of Defence website [9]).

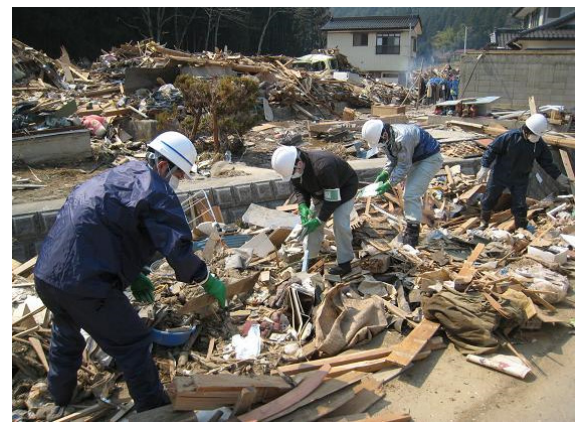

Figure 4: Support by domestic local government (Reference: Toyoka, Hyogo website [10]). 


\section{Contents and benefits of this study}

In this study, Chapter 4 ascertains 1554 local governments' actual support conditions. Intended governments not including them were applied to the Disaster Relief Act in The Great East Japan Earthquake [11]. Chapter 5 describes their support motivations. Chapter 6 discusses knowledge obtained by this study.

The study contents are the following:

1) The database used for this study was created by the authors from information about assistance from domestic local governments.

2) The database ensures collectability, completeness of information and a certain level of reliability as data using Japanese local governments' official websites for analysis. This method enables the revitalization of data acquisition.

3) Each local government person in charge of assistance can understand one's own position related to assistance through the presentation of a comprehensive vision of domestic local governments' actual support conditions. Results of this study show information completed with high usefulness to use domestic local governments' assistance.

\section{Compendium of data}

Data used for the study were downloaded from 1554 Japanese local governments' websites, except for those which applied the Disaster Relief Act. Table 2 presents a compendium of data.

Table 2: Compendium of data.

\begin{tabular}{|l|l|}
\hline Date of research & For 3 months from September 2012 \\
\hline Method & Download from Japanese local governments' websites \\
\hline \multirow{2}{*}{ Intended area } & $\begin{array}{l}\text { 1554 Japanese local governments which were not applied } \\
\text { the Disaster Relief Act }\end{array}$ \\
\hline \multirow{4}{*}{ Item } & $\begin{array}{l}\text { Description contents about supply of goods and physical } \\
\text { support }\end{array}$ \\
\cline { 2 - 2 } & Description contents about the disaster-affected area \\
\cline { 2 - 2 } & Description contents about motivation of assistance \\
\hline
\end{tabular}

Data were collected from websites under strict rules to produce objective analyses. Descriptions on websites were related with their assistance efforts after The Great East Japan Earthquake such as charitable donations or activities, supply of goods, physical support, provision of municipal housing, and recruiting of field activities.

The database was created from extracted information, including their contexts, from numerous websites. The extracted information included descriptions of the presence or absence of assistance, victims and destinations of assistance, etc.

Some local governments do not show information related to disaster assistance on their websites. Presumably, most of them did not participate in 
supporting activities. Nevertheless, some governments which actually supported the affected area chose not to present that information related to the websites. That inconsistency remains as a limitation of the approach used by this study. However, it does not degrade the value of this study much because no further realistic means exists to achieve the objective of this work.

\section{Local governments' actual support conditions in natural disasters}

This chapter presents local governments' actual support conditions. Information is arranged according to differences in assistance system functions. Assistance was given by adjustment for physical support from Japanese Reconstruction Agency or Ministry of Internal Affairs and Communications, and local governments' own assistance such as individual adjustment between recipients of assistance and providers of assistance or local governments providing mutual assistance, local governments which concluded mutual disaster relief agreements, etc. Results of this study show local governments' actual support conditions in three categories: Assistance by adjustment for physical support from country is designated as "job-related assistance", local governments" own assistance is designated as "voluntary assistance", and the assistance with unclarified motivation is designated as "unsourced assistance".

Figure 5 presents local governments' actual support conditions in three categories. Furthermore, Figure 6 shows overlapping category in domestic local governments supported the disaster-affected area. The considerations are the following.

1) As shown in Figure 5, about half of the governments implemented jobrelated assistance. Of the governments, 31.3\% implemented voluntary assistance. Furthermore, unsourced assistance accounts for $40.0 \%$ of all governments.

2) Figure 6 shows that $30.7 \%$ of governments presumably extended no support; $69.3 \%$ of the governments implemented assistance under some of the following categories.

3) As shown in Figure 6, 14.7\% of the governments implemented a combination of job-related assistance and unsourced assistance. Domestic local government support of the disaster-affected areas is the largest category. The second largest category is government-implemented unsourced assistance, accounting for $12.0 \%$ of the total. Of the governments, $11.8 \%$ implemented a combination of job-related-assistance and voluntary assistance. Furthermore, $11.3 \%$ of the government implemented job-related assistance only; $6.2 \%$ of the government implemented voluntary assistance only.

Figures 7-10 portray the contents implemented as assistance by domestic local governments according to three categories: supply of goods, physical support, and other support. Each figure shows local governments' actual support 


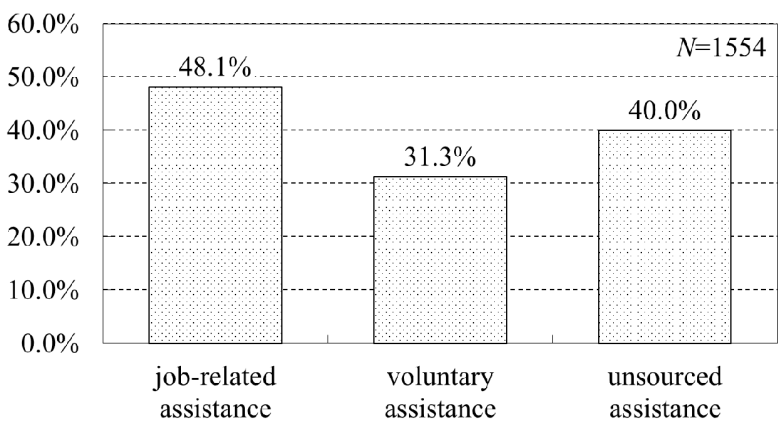

Figure 5: Percentage of assistance provided by domestic local governments supporting the affected area.

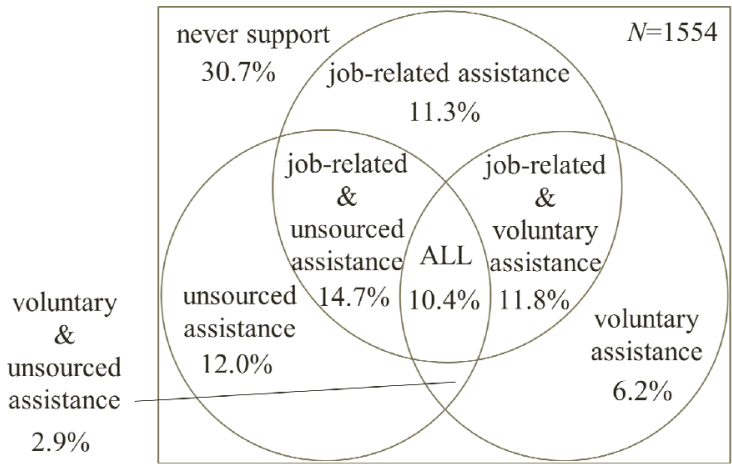

Figure 6: Overlapping relations of the category in domestic local governments supported the affected area.

conditions from governments of different levels: large/mid-sized cities, small cities, and town and villages. The considerations are the following.

1) In Figures 7-10, job-related assistance is shown to have a high percentage of physical support. It shows that systematic physical support was implemented to the disaster-affected area by adjustment for physical support from the nation and assistance by firefighting teams.

2) Voluntary assistance shows a high percentage of supply of goods compared to physical support, which shows the different trend of assistance.

3) In Figures 7-9, physical support was implemented for job-related-assistance more than for the supply of goods in large/mid-sized cities, small cities, and towns. The supply of goods was implemented as for job-related more than physical support at the village level. Regarding voluntary assistance, only $0.6 \%$ of the physical support was implemented at the village level, which shows that assistance of different types was implemented based on the level of government administration. 


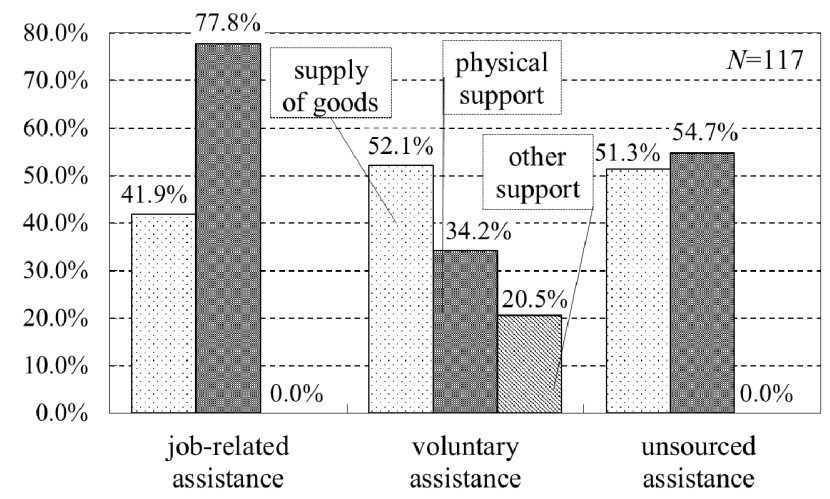

Figure 7: Percentage of assistance by large/mid-sized cities.

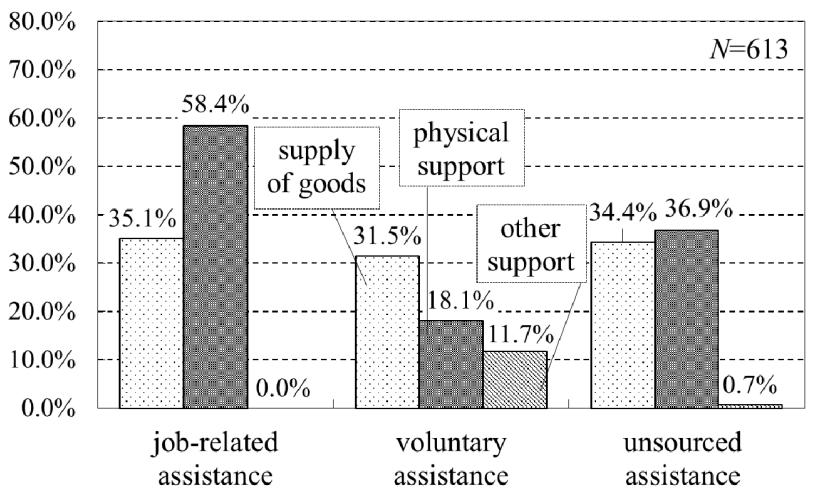

Figure 8: Percentage of assistance by small cities.

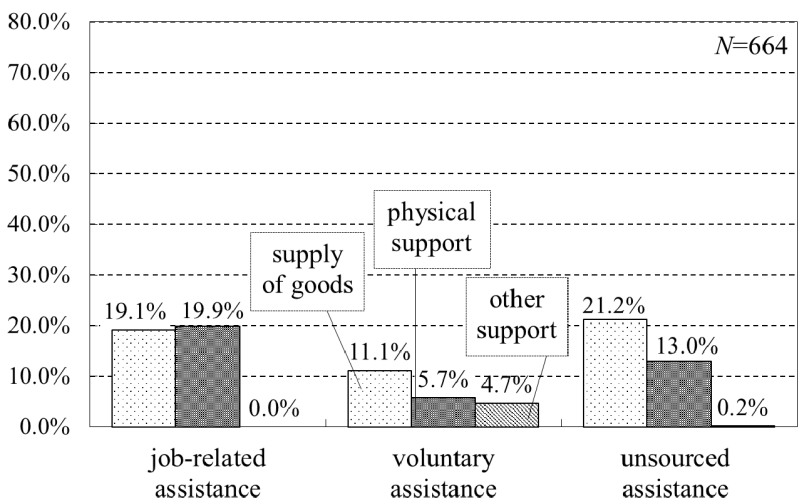

Figure 9: Percentage of assistance by towns. 


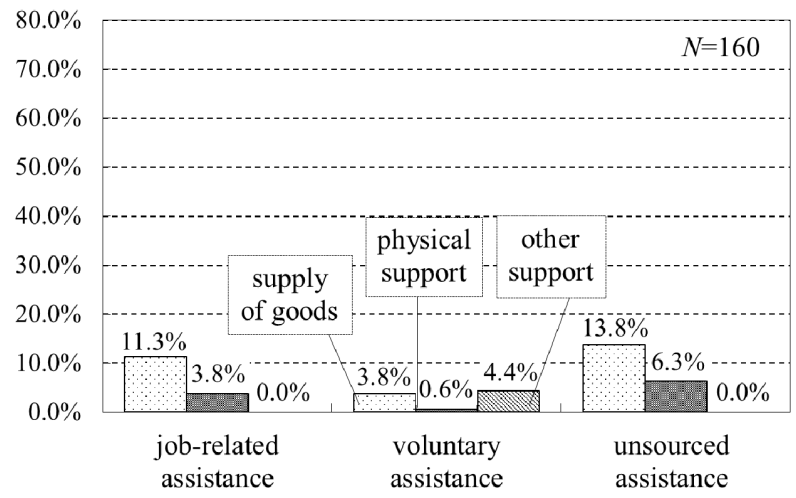

Figure 10: Percentage of assistance by villages.

\section{Motivation of assistance by domestic local governments}

This chapter presents the motivation of voluntary assistance by domestic local governments. This study analyzed all aspects of Japanese local government websites, particularly examining their support motivation. Each motivation is shown in a dedicated list for the motivation of assistance consisting of 17-items and eight categories. This is presented in Table 3.

The category contents are the following. "Request" denotes assistance requested by the disaster-affected area. "Conclusion" stands for assistance implemented for the friendship city or the government concluded disaster relief agreements with. "Fold" is assistance implemented through conference or association affiliated each other. "Exchange" is assistance implemented to the government established cultural ties each other, or have assisted in the past. This category includes the mayor's visit to the disaster-affected area while the earthquake disaster reconstruction. "Culture" is assistance implemented to the government which has similar historic or cultural background, contains same letter in its city name, etc. "Cooperation" is assistance implemented in close coordination and cooperation with neighborhood area, etc. Figure 11 exhibits the motivations of voluntary assistance for different levels of government: large/mid-sized cities, small cities, towns, and villages. The considerations are the following.

1) In Figure 11, "Request" from the disaster-affected area, assistance by a friendship city, and disaster relief agreements affected the motivation of assistance in large/mid-sized cities.

2) In small cities and towns, assistance implemented in close coordination and cooperation with neighborhood areas occupies a high percentage of motivation of assistance. It has the effect of decreasing the burden of each assistance provider.

3) In towns, motivation of assistance was based mainly on association or relationships of residents or the experience of assistance in the past. Furthermore, assistance was also implemented to the friendship city at village. 
Table 3: Motivations of voluntary assistance.

\begin{tabular}{|c|c|}
\hline \multicolumn{2}{|c|}{ List of motivations of voluntary assistance } \\
\hline Category & Item \\
\hline A. Request & A-1. Request from the disaster-affected area \\
\hline \multirow{2}{*}{ B. Conclusion } & B-1. Friendship city \\
\hline & B-2. Disaster relief agreements \\
\hline \multirow{2}{*}{ C. Fold } & C-1. Conference related \\
\hline & C-2. Association affiliated \\
\hline \multirow{5}{*}{ D. Exchange } & D-1. Established cultural ties each other in past \\
\hline & D-2. Established at events \\
\hline & D-3. Established people each other \\
\hline & D-4. Assisted in past \\
\hline & $\begin{array}{l}\text { D-5. Visiting to the disaster-affected area by mayor of } \\
\text { providers of assistance }\end{array}$ \\
\hline \multirow{3}{*}{ E. Culture } & $\begin{array}{l}\text { E-1. Government have similar historic or cultural } \\
\text { background }\end{array}$ \\
\hline & $\begin{array}{l}\text { E-2. Government contains same letter city's name of } \\
\text { each other }\end{array}$ \\
\hline & E-3. Support of specialty goods \\
\hline \multirow{2}{*}{ F. Cooperation } & F-1. Relation to neighborhood area \\
\hline & F-2. Delegated support to company in the city, etc. \\
\hline G. Other & G-1. Other \\
\hline $\begin{array}{l}\text { H. Unclear motivation of } \\
\text { assistance }\end{array}$ & H-1. Unclear motivation of assistance \\
\hline
\end{tabular}

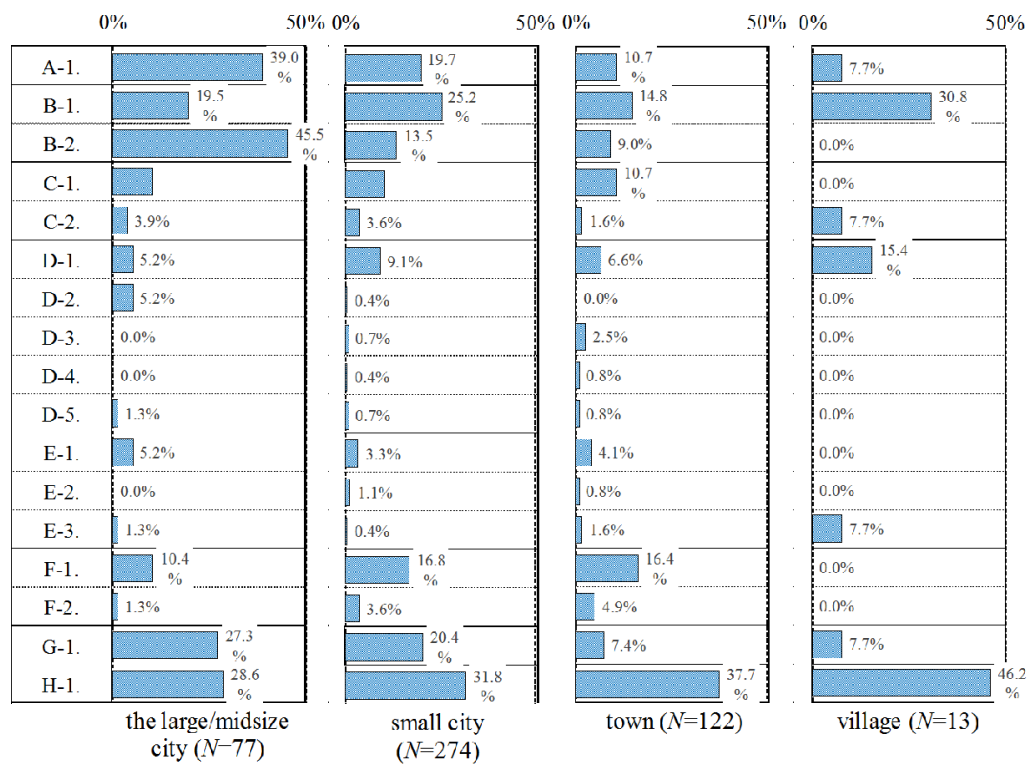

( $N$ : Domestic local governments providing support)

Figure 11: Motivation of voluntary assistance at different levels of government. 
The motivation of voluntary assistance affects intergovernmental exchange, cultural background, and daily relationships with neighborhood areas based on these considerations.

\section{Conclusions}

Results that this study provided are the following.

1) Job-related assistance accounts for a high percentage of physical support more than it accounts for a supply of goods. That result shows that systematic physical support was implemented to disaster-affected areas by adjustment for physical support from the national government and assistance from firefighting teams. However, voluntary assistance accounts for a high percentage of the supply of goods.

2) In job-related and voluntary assistance, the percentages of the supply of goods and physical support decrease as the level of government decreases from large/mid-sized cities to villages. That result shows that local governments' actual support conditions are affected by the scale of governments. That result is prominent especially for voluntary assistance.

3) For large/mid-sized cities, the motivation for assistance is affected by requests from the disaster-affected areas, assistance of affiliated cities, and mutual disaster relief agreements.

4) In towns, assistance was implemented based on close coordination and cooperation with the neighborhood area.

5) Results show that voluntary assistance was rendered to governments having some connections. Some reason is necessary for assistance from domestic local governments because tax revenues must be allocated for use as assistance.

6) Relations among local governments are important to facilitate their voluntary assistance to other regions and their government associations. Moreover, daily interregional exchange can support mutual assistance in extreme situations.

\section{References}

[1] GFDRR in World Bank, the profound lesson from The Great East Japan Earthquake, http://siteresources.worldbank.org/JAPANINJAPANESEEXT /Resources/515497-1349161964494/KnowledgeNote_ALL.pdf (accessed on 23 January, 2015).

[2] Japanese Cabinet Office, the estimate of disaster damage from The Great East Japan Earthquake, http://www.bousai.go.jp/2011daishinsai/pdf/ 110624-1 kisya.pdf (accessed on 23 January, 2015).

[3] EM-DAT, http://www.emdat.be/ (accessed on 23 January, 2015).

[4] Y. Higuch, T. Inui, S. Sugiyama, K. Wakabayashi, N. Kuga, T. Hosoi, K. Ikemoto, I. Takabe, Y. Uematsu and T. Arimitsu, Aftermath of the 3.11 Disaster: An Analytical Evaluation Using Official Statistics, Japanese Cabinet Office, ESRI Discussion Paper Series No. 286, April 2012. 
[5] Fire and Disaster Management Agency, White Paper on Extinguishing fire on 2011.

[6] Japanese Cabinet Office, About The Great East Japan Earthquake, http://www.bousai.go.jp/2011daishinsai/pdf/torimatome20140911.pdf (accessed on 23 January, 2015).

[7] Reconstruction Agency, Condition of physical support by Ministry of Internal Affairs and Communications, http://www.reconstruction.go.jp/ topics/20130306_syoutyou_soumu.pdf (accessed on 23 January, 2015).

[8] Ministry of Internal Affairs and Communications, About support by Ministry of Internal Affairs and Communications and domestic local governments, http://www.soumu.go.jp/menu_kyotsuu/important/kinkyu03 000015.html (accessed on 23 January, 2015).

[9] Ministry of Defence, Condition of support by the Self-Defence Forces at disaster-affected area, http://www.mod.go.jp/js/Activity/Gallery/touhoku_ earthquake_g02.htm (accessed on 23 January, 2015).

[10] The site of Toyoka, Hyogo, http://www.city.toyooka.lg.jp/www/contents/ 1305078024426/index.html (accessed on 23 January, 2015).

[11] Disaster Countermeasure Basic Act, http://law.egov.go.jp/htmldata/ S36/S36HO223.html (accessed on 23 January, 2015). 